\title{
Occurrence of Neophilopterus tricolor (Burmeister, 1838) on a black stork (Ciconia nigra) in the Kızılırmak Delta, Turkey
}

\author{
Mustafa AÇICI ${ }^{1, a, ~}{ }^{凶}$, Gökhan EREN ${ }^{1, b}$, Ömral Ünsal ÖZKOÇ,c, Mehmet ÖZTÜRK ${ }^{1, d}$, \\ Cenk Soner BÖLÜKBAŞ⿻ి

\begin{abstract}
${ }^{1}$ Ondokuz Mayıs University, Faculty of Veterinary Medicine, Department of Parasitology, Samsun; ${ }^{2}$ Ondokuz Mayıs University, Faculty of Arts and Science, Department of Biology, Samsun, Turkey ${ }^{\mathrm{a}} 0000-0002-8406-9739 ;{ }^{\mathrm{b}} 0000-0002-2109-5059 ;$ c $0000-0002-5918-8664 ; ~^{\mathrm{d}} 0000-0002-3559-0587$; ${ }^{\mathrm{e}} 0000-0002-4863-696 \mathrm{X}$
\end{abstract}

Corresponding author: acicim@omu.edu.tr

Received date: 15.04.2020 - Accepted date: 13.09.2020

\begin{abstract}
A dead black stork (Ciconia nigra) was found by an a birdwatcher in the Kizılirmak Delta near Samsun, Turkey and brought to the Parasitology Laboratory of the Faculty of Veterinary Medicine at Ondokuz Mayis University for ectoparasitological examination in December 2019. During the examination, 45 specimens of chewing lice (21 males, 18 females and 6 nymphs) were collected. All of the specimens were identified as Neophilopterus tricolor (Burmeister, 1838) (Ischnocera: Philopteridae). Neophilopterus tricolor is reported from the black stork (C. nigra) for the first time in Turkey.

Keywords: Black stork, Ciconia nigra, Neophilopterus tricolor, Philopteridae, Phthiraptera.
\end{abstract}

\section{Türkiye’de Kızılırmak Deltası'nda, bir kara leylekte (Ciconia nigra) Neophilopterus tricolor (Burmeister, 1838) olgusu}

Özet: Samsun'da Aralık 2019'da, Kızılırmak Deltası'nda, bir kuş gözlemcisi tarafından bir adet ölü kara leylek (Ciconia nigra) bulunmuş ve ekto-parazitolojik incelemesi yapılmak üzere Ondokuz Mayıs Üniversitesi Parazitoloji Anabilim Dalı Laboratuvarı'na getirilmiştir. Ektoparazitik muayenede 45 örnek (21 erkek, 18 dişi ve 6 nimf) incelenmiş ve tümü Neophilopterus tricolor (Burmeister, 1838) (Ischnocera: Philopteridae) olarak tanımlanmıştır. Neophilopterus tricolor Türkiye'de ilk kez bir kara leylekte (C. nigra) rapor edilmiştir.

Anahtar sözcükler: Kara leylek, Ciconia nigra, Neophilopterus tricolor, Philopteridae, Phthiraptera.

In studies conducted on domestic and wild birds, over 4000 Mallophaga (Amblycera, Ischnocera) species have been identified worldwide $(1,3,18)$. Phthiraptera species are obligatory ectoparasites that spend their entire life cycle on the host; they are obliged to leave their host within a short time after its death and find another host or they cannot survive for more than a short period (2). About 100 species of lice have been reported from domesticated and wild birds in Turkey $(7,12)$.

There are three species in the bird family Ciconiidae (Order Ciconiiformes), namely the black stork (Ciconia nigra), white stork (Ciconia ciconia) and yellow-billed stork (Mycteria ibis); only the chewing lice fauna of the white stork (C. ciconia) have been studied in Turkey (6, 11, 13). The ectoparasitic genera, Ardeicola, Ciconiphilus,
Colpocephalum, Laemobothrion and, Neophilopterus, have been recorded on storks (18). Usually, chewing lice infestations are seen on all birds in the same nest $(4,16)$.

The aim of the present study was to identify the species of chewing lice removed from a black stork $(C$. nigra) found dead in the Kizılırmak Delta in Samsun Province, Turkey.

A one-year old, black stork found dead in the Kizılırmak Delta by an a birdwatcher was brought to the Parasitology Laboratory of the Veterinary Faculty at Ondokuz Mayis University in Samsun, Turkey for examination in December 2019. After the ectoparasitological examination, the collected material, namely chewing lice, was preserved in $70 \%$ ethyl alcohol before processing. For identification purposes, the 
specimens were mounted on slides, according to the Canada Balsam technique (17). After mounting, the specimens were examined under a stereo-microscope (Nicon SMZ 1500) and then diagnosed according to the keys of Cummings (5) and Lanzarot et al. (14). The male genital organ was drawn with the aid of InkScape (Version 0.92).

In this study, a total of 45 chewing lice specimens (21 males, 18 females and 6 nymphs) were collected from a dead black stork. All of the specimens were Neophilopterus tricolor (Burmeister, 1838) (Philopteridae).

The head of $N$. tricolor (Burmeister, 1838) was large and triangular, the front edge was slightly concave, the width of the head was greater than its length. The preantennal region was shorter than the postantennal region. There were 6 marginal temporal setae, 4 long and 2 short (Figure 1A, B). Thoracic width was greater than the length. The prothorax and pterothorax were clearly separated in females and males (Figure 1A, B, C).
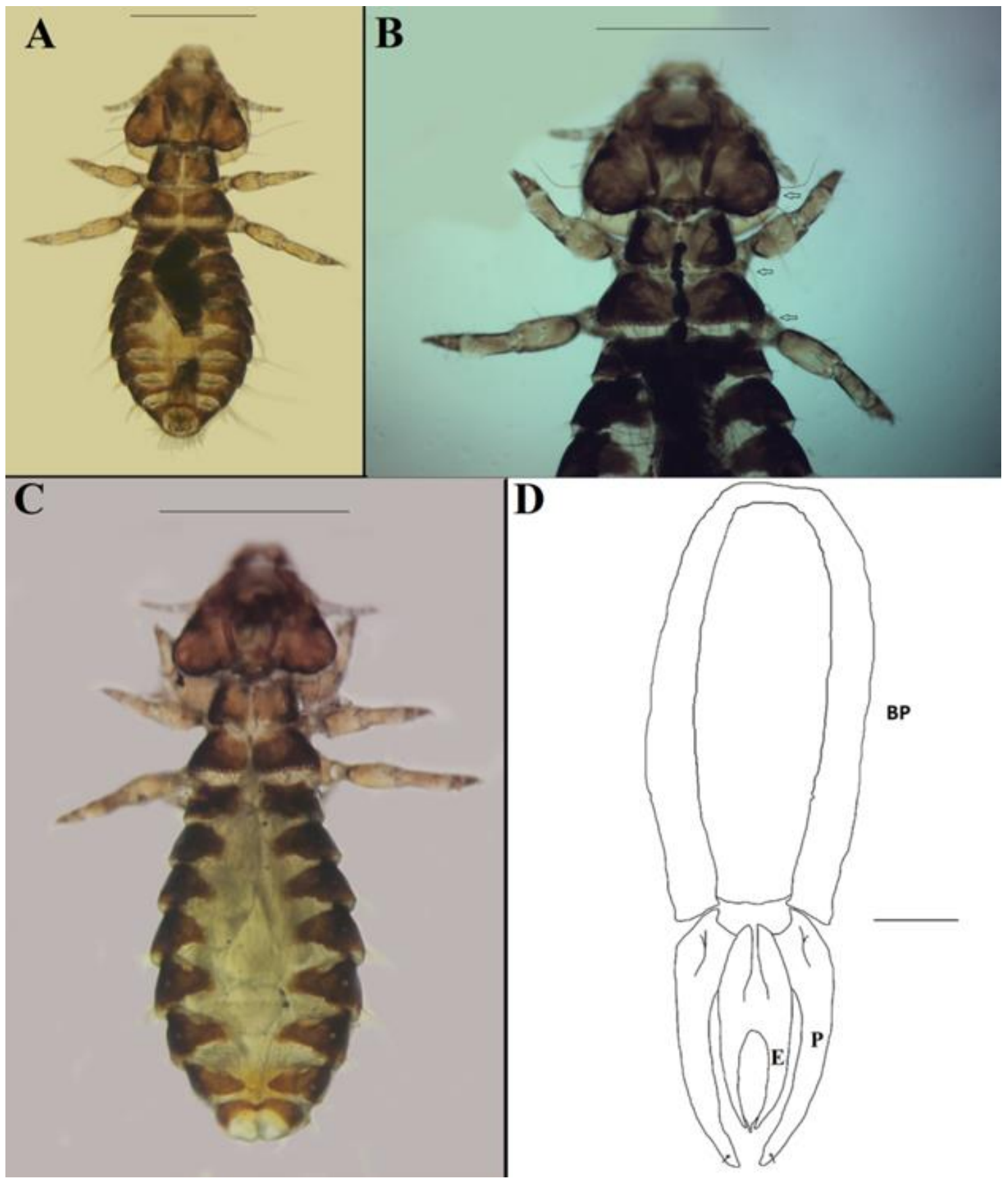

A: Male, B: Female (Setae of head and thorax, arrows), C: Female (Scale bar: 1mm); D: Male genitalia (BP: Basal plate, E: Endomeral plate, P: Paramere) (Scale bar: $50 \mu \mathrm{m})$.

Figure 1. Neophilopterus tricolor. 
The posterolateral corners of the prothorax were rounded. On both sides of the prothorax, there were $2+2$ setae, one long and one short. There were 24 setae, $12+$ 12 , on the posterior edge of the pterothorax (Figure 1B). There were two rows of tergal setae on each segment, with 10-15 setae distally and 8-10 setae in the central area.

The basal plate was convex and longer than the parameres. The area of the basal plate was groove-shaped. The parameres were wide, rounded, slightly curved inward and tapering towards the distal end. At the end of the endomeral plates, there was a membrane-like penis located between the basal endomeral region (Figure 1D).

There have been a number of studies on the chewing lice species of white storks in Turkey $(6,8,9,10,11)$. Dik and Uslu (6), Dik et al. (8) and İnci et al. (11) reported the infestation of white storks with four different chewing lice species, Ardeicola ciconiae, Ciconiphilus quadripustulatus, Colpocephalum zebra and $N$. incompletus, in Turkey. In the present study, 45 chewing lice specimens were removed from a black stork found dead in the Kizılirmak Delta; all of the specimens were from the same species, $N$. tricolor.

Neophilopterus tricolor (Burmeister, 1838) is morphologically similar to N. incompletus (Denny, 1842), which has been reported to infest $C$. nigra (14). These species are host specific to $C$. ciconia and $C$. nigra, respectively (14). However, the morphological characters of the two species are slightly different; they can be easily distinguished via the differences in the genital area and mesosoma (5). In addition, the marginal setae on the temples were compared by Zlotorzycka (19) who reported six temporal marginal setae (four long and two short) on $N$. tricolor and five temporal marginal setae of almost the same length on $N$. incompletus. Another difference is the positions of the tergal setae in the abdominal segments: there are two rows of abdominal tergal setae, one apical and the other on the midline of the segment, in N. tricolor, and two rows, one apical and one basal, in N. incompletus $(14,15)$.

In the present study, Neophilopterus tricolor is reported for the first time from the black stork in the Kizılırmak Delta in Turkey.

\section{Acknowledgement}

The authors are grateful to Gregory T. Sullivan his assistance in editing.

\section{Financial Support}

This research received no grant from any funding agency/sector.

\section{Ethical Statement}

This study does not present any ethical concerns.

\section{Conflict of Interest}

The authors declared that there is no conflict of interest.

\section{References}

1. Burmeister HCC (1838): Mallophaga Nitzsch. In: TChF Enslin (Ed), Handbuch der Entomologie 2(2): Gymnognata. Berlin: G Reimer.

2. Clay T (1949): Some problems in the evolution of a group of ectoparasites. Evolution, 3, 279-299.

3. Clay T (1951): An introduction to a classification of the avian Ischnocera (Mallophaga): Part I. Trans R Entomol Soc Lond, 102, 171-194.

4. Cramp S, Simmons KEL (1977): Handbook of the Birds of Europe, the Middle East and North Africa: The Birds of the Western Paleartic. Volume 1, Ostrich to Ducks. New York: Oxford University Press.

5. Cummings BF (1916): Studies on the Anoplura and Mallophaga, being a report upon a collection from the mammals and birds in the Society's Gardens, Part II. Proc Zool Soc Lond, 86, 643-693.

6. Dik B, Uslu U (2006): Mallophaga (Insecta) species occurring on storks (Ciconia ciconia Linnaeus, 1758). Türkiye Parazitol Derg, 30, 220-225.

7. Dik B, Kirpik MA, Sekercioğlu C, et al (2011): Chewing lice (Phthiraptera) found on songbirds (Passeriformes) in Turkey. Turkiye Parazitol Derg, 35, 34-39.

8. Dik B, Erdoğdu Yamaç E, Uslu U (2011): Chewing lice (Phthiraptera) Found on Wild Birds in Turkey. Kafkas Univ Vet Fak Derg, 17, 787-794.

9. Girișgin AO, Dik B, Girișgin O (2013): Chewing lice (Phthiraptera) species of wild birds in northwestern Turkey with a new host record. Int J Parasitol, 2, 217-221.

10. Göz Y, Dik B, Kılınç ÖO, et al (2015): Chewing Lice Phthiraptera: Amblycera, Ischnocera) on several species of wild birds around the Lake Van basin, Van, eastern Turkey. Kafkas Univ Vet Fak Derg, 21, 333-338.

11. İnci A, Dik B, Kibar M, et al (2010): Chewing Lice (Phthiraptera) species on wild birds in Cappadocia Region, Turkey. Turkiye Parazitol Derg, 34, 174-178.

12. İnci A, Yildirim A, Dik B, et al (2010): Current knowledge of Turkey's louse fauna. Turkiye Parazitol Derg, 34, 212220.

13. Kirwan G, Boyla KA, Castell P, et al (2010): The Birds of Turkey. London: Christopher Helm. Available at https://www.bloomsbury.com/uk/the-birds-of-turkey9781408104750/ (Accessed March 01, 2020).

14. Lanzarot MP, Martín-Mateo MP, Merino S, et al (2005): A redescription of Neophilopterus tricolor (Burmeister, 1838) (Insecta: Phthiraptera: Ischnocera: Philopteridae) from the black stork Ciconia nigra (L.) (Aves) with notes on its prevalence. J Nat Hist, 39, 3471-3480.

15. Martin Mateo MP (1988): Malo'fagos (Insecta) para'sitos de ciguen a comu'n, Ciconia ciconia (L.) (Aves). Eos, 64,147-158.

16. Miller MJR, Ewins PJ, Galloway TD (1997): Records of ectoparasites collected on ospreys from Ontario. J Wildl Dis, 33, 373-376. 
17. Palma RL (1978): Slide-mounting of lice: a detailed description of the Canada balsam technique. N Z Entomol, 6, 432-436.

18. Price RD, Hellenthal RA, Palma RL (2003): The Chewing Lice: World Checklist and Biological Overview. Illinois Natural History Survey Special Publication, USA.
19. Zlotorzycka J (1980): Klucze oznaczania owado'w ppdki. XV, Mallophaga 6. Warszawa-Wroclaw: Polish Entomological Society. 